\title{
Peran Guru Pendidikan Agama Islam Dalam Menanamkan Nilai- Nilai Ahlussunnah Wal Jama'ah Pada Siswa MTs Nurul Huda Kedopok Kota Probolinggo
}

\author{
Yulistian Hartini, Devy Habibi Muhammad, Ari Susandi \\ Sekolah Tinggi Agama Islam Muhamadiyah Kota Probolinggo \\ * Corresponding Author. E-mail:syifaajwa31@gmail.com, hbbmuch@gmail.com, \\ pssandi87@gmail.com
}

Receive: 13/05/2021

Accepted: $23 / 08 / 2021$

Published: 01/10/2021

\begin{abstract}
Abstrak
Tujuan penelitian ini bertujuan untuk mengetahui pembelajaran, upaya guru Pendidikan Agama Islam serta mengetahui akibat dari upaya Pendidikan Agama Islam dalam menanamkan nilai-nilai Ahlussunnah Wal Jama'ah Pada Siswa"MTs Nurul Huda. Penelitian ini dirancang dengan pendekatan deskriptif kualitatif dengan teknik pengumpulan data berupa wawancara obeservasi dan dokumentasi. Adapun teknik analisis data yang digubakan adalah reduksi data, display/ penyajian data, verifikasi data dan penarikan kesimpulan. Berdasarkan analisis data dalam penelitian ini, dapat disimpulkan bahwa. 1) Pelaksanaan pembelajaran materi Ahlussunnah Wal Jama'ah pada Siswa Kelas 4 MTs Nurul Huda.sudah sesuai dengan materi pembelajaran dan tujuan pembelajaran dengan menggunakan Rencana Program Pembelajaran Aswaja, pengamalan Tawasuth, i'tidal, Tasamuh, Tawazun, Amr Ma'ruf Nahi Munkar, dengan menggunakan metode ceramah dan diskusi. 2) dampak penanaman nilai-nilai Ahlussunnah Wal Jama'ah Pada Siswa MTs Nurul Huda adalah siswa dapat memiliki budi pekerti yang berakhlak, memiliki toleransi kepada teman serta, memiliki rasa patuh kepada orang tua dan pengajar di sekolah.
\end{abstract}

Keywords: Guru Pendidikan Agama Islam, Ahlussunnah Wal Jama'ah

\begin{abstract}
The purpose of this study aims to know learning, the efforts of Islamic Education teachers and know the impact of Islamic Religious Education efforts in instilling ahlussunnah Wal Jama'ah values in MTs Nurul Huda students. This research is designed with a qualitative descriptive approach with data collection techniques in the form of interviews and documentation. The data analysis techniques that are blemoaned are data reduction, data display / presentation, data verification and conclusion withdrawal. Based on the analysis of the data in this study, it can be concluded that. 1) The implementation of Ahlussunnah Wal Jama'ah material learning in Students of Grade 4 MTs Nurul Huda.is in accordance with learning materials and learning objectives by using the Aswaja Learning Program Plan, Tawasuth practice, i'tidal, Tasamuh, Tawazun, Amr Ma'ruf Nahi Munkar, using lecture and discussion methods. 2) The impact of planting ahlussunnah Wal Jama'ah values on MTs Nurul Huda students is that students can have ethics that are wise, have tolerance to friends as well as, have a sense of tawadlu' to parents and teachers in school.
\end{abstract}

Keywords: Teacher of Islamic Religious Education, Ahlussunnah Wal Jama'ah 


\section{Pendahuluan}

Masa remaja ialah era yang amat mendukung buat adaptasi sikap keimanan, semacam adaptasi mendirikan sholat 5 waktu, adaptasi membaca kitab suci Al qur' an, adaptasi berdo'a, adaptasi mengabdi pada orang tua, serta yang lain. pembiasaan ini apabila dicoba dengan manajemen serta tata cara serta strategi yang pas bisa menumbuh kembangkan nilai- nilai akhlaq karimah untuk mereka (Ali Rohmad, 2009). Guna menghasilkan seluruh itu hingga, diperlukannya adanya usaha dari seseorang guru ataupun seseorang pengajar. Dalam pemikiran Islam tidak cuma diperuntukkan pada satu kelompok atau daerah saja, melainkan pemikiran Islam untuk semua manusia yang terletak di alam semesta ini. Tetapi begitu, arsitektur universalitas Islam dalam kalangan pemeluk mukmin sendiri tidak sering sesuai (Adawiyah, 2019).

Pembelajaran menggambarkan aktivitas yang terdiri dari 2 orang maupun lebih antara pengajar dengan partisipan ajar guna menggapai tujuan pembelajaran yang sudah ditetapkan (Mujayyanah, 2021). Aktivitas ini bisa berjalan dalam sekolah, keluarga, atau lingkup penduduk. Prinsip pembelajaran yang Islami merupakan memajukan penataran yang menggambarkan orang orang islam, yang positif buat anak didik ataupun pengajar. Dalam susunan pengajaran serta penataran wajib ditempatkan selaku pengayaan dalam pengalaman keTuhanan. Pembelajaran itu bukan cuma hal internalisasi wawasan ataupun pemasyarakatan serta kesepakatan pengajar, akibatnya anak didik diharapkan mengalami keahlian yang mereka alami sendiri.(Muhammad, 2020)

Out put yang di impikan ialah terwujudkan angkatan yang berakhlak, beretika serta terhormat dalam sikap sosial. Pembelajaran agama tidak lumayan pada tataran mengarahkan harapan serta aturan metode ibadah pada Si Khaliq, tetapi diharapkan hendak dapat berfungsi aktif guna menekan anak didik lebih maju, dan guna kehidupan yang lebih beradab dengan dasar etika sosial yang tepat(Prasetiya et al., 2018). Oleh karena itu, Ahlus Sunnah Wal Jama' ah yang disingkat ASWAJA yang memiliki nilai- nilai Tawasuth, I' tidal, Kesabaran, Tawazun Amr Ma' ruf Nahi Munkar yang dikira yang sangat cocok dengan Islam yang terletak di Indonesia. Sebab Ahlussunnah Wal Jamaah yang gampang diperoleh oleh mayoritas warga. Di era saat ini, terdapat banyak yang bermunculan aliran- aliran yang berterus terang ahlu sunnah. Namun di lembaga sekolah MTs Nurul Huda ini yang berada dalam antusias serta berpegang teguh dalam penyebaran Ahlus Sunnah Wal Jama' ah, serta otomatis pastinya tidak lupa untuk menegakkan pemikiran ataupun nilai-nilai Ahlussunnah Wal Jamaah ialah bisa lewat modul penataran Ahlussunnah Wal Jamaah( ASWAJA) ataupun penerapan nilai- nilai tawasuth, i' tidal, kesabaran, tawazun serta amr ma' ruf nahi munkar serta tidak lupa mengamalkan penerapan amaliyah Ahlus Sunnah Wal Jama' ah.

Peserta didik disaat ini tengah banyak kita jumpai sedang rendahnya wawasan mengenai nilai- nilai agama islam bisa kita amati masih banyak Peserta didik dari tingkatan dasar yang belum mampu bawa mereka pada pergaulan yang positif semacam rasa tanggung jawab mereka dalam tiap kegiatan yang mereka jalani serta pula terdapat sekian banyak permasalahan selalu terjalin perbedaan temani Peserta didik dan juga rasa sayang serta kebebasan mereka yang sedang sedikit, sebab pola dari penanaman nilai- nilai agama islam mereka sedang kurang, 
paling utama dalam angka kejujuran, kedisplinan, tanggung jawab serta kebebasan.(Susandi, 2019)

Dari uraian latar belakang diatas maka Rumusan masalah dalam penelitian ini yaitu: 1)Bagaimana pembelajaran materi Ahlussunnah Wal Jama'ah Pada Siswa MTs Nurul Huda? 2)Bagaimana upaya guru Pendidikan Agama Islam dalam menanamkan nilainilai Ahlussunnah Wal Jama'ah Pada Siswa MTs Nurul Huda? 3) Bagaimana dampak dari upaya Pendidikan Agama Islam dalam menanamkan nilai-nilai Ahlussunnah Wal Jama'ah Pada Siswa MTs Nurul Huda?

Adapun tujuan penelitian ini adalah sebagai berikut: 1) untuk mengetahui pembelajaran materi Ahlussunnah Wal Jama'ah Pada Siswa MTs Nurul Huda. 2) Untuk mengetahui upaya guru Pendidikan Agama Islam dalam menanamkan nilai-nilai Ahlussunnah Wal Jama'ah Pada Siswa MTs Nurul Huda. 3) Untuk mengetahui dampak dari upaya Pendidikan Agama Islam dalam menanamkan nilai-nilai Ahlussunnah Wal Jama'ah Pada Siswa MTs Nurul Huda.

\section{Ahlussunnah Wal Jama'ah}

Ahlussunnah Wal Jama' ah maupun yang lazim disingkat dengan Aswaja berawal dari sabda Ahlun yang maksudnya keluarga, kalangan, serta pengikut. ASWAJA kepanjangan dari“ Ahlussunnah Wal Jama' ah". Maksudnya banyak orang yang menganut ataupun menjajaki sunnah Nabi Muhammad Saw, serta Wal Jama' ah berarti kebanyakan pemeluk ataupun menjajaki sunnah Nabi Muhammad Saw. Jadi, arti Ahlussunnah Wal Jama' ah ialah:" banyak orang yang menjajaki sunnah Rasul serta kebanyakan kawan( maa ana alaihi wa ashabihi), bagus di dalam syariat( hukum Islam) ataupun kepercayaan serta kebatinan." Jejak Rasul Muhammad Saw serta membelanya. Mereka terdapat yang diujarkan dengan salaf ialah keturunan dini mulai dari kawan, Tabi' in, Tabi' (AL)
Tabi' in serta terdapat pula yang diucap Khalaf ialah keturunan yang tiba setelahnya hingga pada umara' 'ulama' (Munawir, 2016).

Dari penjelasan di atas, bisa dimengerti jika Ahlussunnah Wal Jama' ah tidaklah gerakan terkini yang timbul selaku respon dari sebagian gerakan yang menyimpang dari anutan Islam yang sesungguhnya. Lebih dari itu, Ahlussunnah Wa al- Jama' ah merupakan Islam yang asli selaku yang diajarkan Rasul Saw serta para teman- temannya (Mahbubi, 2017). Sebutan Ahlussunnah Wal Jamaah memiliki sebutan yang serupa dengan Ahlussunnah. Hingga dari itu sunnah tandingan dari sabda bid' ah, sebaliknya jama' ah tandingan sabda dari firqah( kaum). Seperti itu yang dimaksudkan dalam hadis- hadis mengenai peranan berjamaah serta hambatan bercerai- berai.

Teori Ahlussunnah Wal Jamaah yang ditawarkan oleh Said Aqil Siradj merupakan selaku man hajr( tata cara berfikir), menyiratkan kalau Ahlussunnah Wal Jamaah bukan telak dipunyai olehg kaum terpilih. Oleh karenanya, bisa dimengerti kalau rancangan Aswaja itu bisa melingkupi bermacam gerakan yang mengklaim diri mereka Aswaja, terlebih lagi non- Aswaja sekalipun (Sary, 2017). Ahlus Sunnah Wal Jama' ah telah terdapat semenjak zaman Rasul, kawan Rasul serta tabi' in yang umumnya diucap dengan dengan" As- Salafus Shalih" opini ini didasarkan pada penafsiran kalau Ahlussunnah Wal Jama' ah berarti kalangan yang loyal pada" Assunnah serta Aljama' ah", ialah Islam yang diajarkan serta diamalkan oleh Rosulullah Saw bersama para teman- temannya pada zaman Rosulullah Saw masih hidup serta apa yang dipraktikkan para sahabat sepeninggal beliau, paling utama para sahabat" Khulafaurrasyidin" (LKS ASWAJA, 2020,). 


\section{Kompetensi Guru Pembelajaran Agama}

Agama Islam Wujud utuh seseorang tamatan program pembelajaran pekerjaan guru terhitung dalam tentang ini guru Pendidikan Agama Islam ( PAI) secara generik tertuang dalam Standar Kompetensi Guru (Permen No. 16 tahun 2007). Kompetensi guru itu awal disusun dengan cara utuh, tetapi pada akhir metode peresmiannya jadi peraturan menteri, diklasifikasikan ke dalam 4 bagian kompetensi dengan kepala karangan semacam tercatat pada Peraturan Pemerintah Nomor 19 tahun 2005 tentang Standar Nasional Pendidikan. Kompetensi inti guru Pendidikan Agama Islam (PAI) dijabarkan sebagai berikut : a) Kompetensi Pedagogik; Dalam Standar Nasional Pendidikan, penjelasan Pasal 28 ayat 3 butir a dikemukakan bahwa: kompetensi pedagogik merupakan keahlian mengatur penataran anggota ajar yang mencakup uraian kepada partisipan ajar, penyusunan serta penerapan penataran, penilaian hasil berlatih, serta pengembangan partisipan ajar buat mengaktualisasikan bermacam kemampuan yang dimiliki. (Mulyasa, 2008,) b) Kompetensi kepribadian; Berperan serupa dengan norma agama, hukum, sosial, serta peradaban nasional Indonesia. Menunjukkan diri selaku individu yang jujur, berbudi pekerti tertinggi, serta panutan untuk partisipan ajar serta warga. Menunjukkan diri selaku individu yang tegas, normal, berumur, arif, serta berkarisma, membuktikan etos aktivitas, tanggungjawab yang besar, rasa senang jadi guru, serta rasa yakin diri. menjunjung atas petunjuk etik pekerjaan guru. c) Kompetensi sosial; Bisa berinteraksi dengan cara positif, efisien, empatik, serta beradab dengan sesama pengajar, kekuatan kependidikan, orang berumur, serta penduduk ataupun pada anggota didiknya.d) Kompetensi professional; Kompetensi handal merupakan kompetensi ataupun keahlian yang berkaitan dengan penanganan tugas- tugas keguruan semacam kemampuan modul serta materi didik. Kompetensi professional ini ialah kompetensi yang amat berarti, karena kompetensi ini langsung berkaitan dengan kemampuan yang diperlihatkan oleh sorang pengajar. Oleh karena itu, tingkatan keprofesionalan seseorang guru bisa diamati dari kompetensi ini (Mulyasa, 2008).

Nilai Nilai Ahlu Sunnah Wal Jamaah

Ahlus Sunnah Wal Jama'ah yaitu pemikiran Islam yang asli seperti di ajarkan oleh Rasulullah Saw serta di amalkan beliau bersama dengan temantemannya. Terdapat 3 sebutan yang di ambil dari al- Qur' an dalam menjelaskan karakter Agama Islam, yaitu Tawassuth, I'tidal, Amar Ma'ruf Nahi Munkar, Tawaazun, Tasamuh.

\section{Metode Penelitian Jenis Penelitian}

Jenis penelitian ini adalah penelitian kualitatif. Dalam hal ini pada jenis penelitian ini yaitu bersifat atau memiliki karakteristik, bahwa datanya dinyatakan dalam keadaan sewajarnya atau sebagaimana adanya (natural setting), dengan tidak diubah dalam bentuk simbol-simbol atau bilangan (Handari \& Nawawi, 2010). Artinya bahwa data perimer adalah sebuah keadaan yang di olah dengan deskripsi keadaan tidak pada simbol atau bilangan. Penulis menggunakan penelitian deskriptif kualitatif. Ada pula yang diartikan dengan riset deskriptif ialah sesuatu riset hanya guna melukiskan sesuatu elastis yang bertepatan dengan permasalahan yang diawasi tanpa memasalahkan ikatan antar variabel (Sugiyono, 2012). Upaya untuk menjelaskan keadaan dirangkum dengan narasi induktif yang menjelaskan hasil akhir dari pencarian informasi. Penelitian ini menggunakan 
pendekatan studi kasus yakni penelitian yang bersifat atau memiliki karakteristik, bahwa datanya dinyatakan dalam keadaan sewajarnya atau sebagaimana adanya (natural setting), disapat dari data lapangan (Hadari \& Nawawi, 2010).

\section{Sumber data primer}

asal usul fakta utama merupakan asal usul informasi yang langsung membagikan informasi pada pengumpul informasi (Sugiyono, 2015). Berbentuk informasi yang digabungkan pengamat langsung dari asal usul kuncinya. Informasi yang didapat langsung dari responden ataupun subjek yang diawasi ataupun terdapat hubungannya dengan subjek yang diawasi, informasi itu dapat didapat langsung dari perorangan yang diawasi serta bisa pula berawal dari lapangan. Dalam riset ini pengarang memperoleh informasi pokok dari lapangan yaitu dari MTs Nurul Huda.

\section{Sumber data sekunder}

Sumber data sekunder adalah sumber yang tidak langsung memberikan data kepada pengumpul data (Sugiyono, 2015). Asal usul informasi sekunder yang diartikan merupakan asal usul informasi yang berhubungan dengan kasus yang pengarang bahas, semacam informasi dari buku- buku, dokumen- dokumen serta yang lain yang bersifat mendukung dalam riset ini.

Metode pengumpulan informasi merupakan metode tersusun serta standar guna mendapatkan informasi yang diperlukan. Pemakaian tehnik serta perlengkapan pengumpulan informasi yang pas membolehkan menemukan informasi yang adil. Metode pengumpulan informasi diantara lain:

1. Observasi

Pemantauan merupakan cara pencatatan pola sikap seorang ataupun peristiwa yang analitis tanpa lewat komunikasi dengan seorang yang diawasi (Nur \& Bambang, 2017). $\begin{array}{lrr}\text { Observasi } & \text { merupakan } & \text { metode } \\ \text { pengumpulan } & \text { informasi } & \text { yang }\end{array}$ memaksimalkan keahlian periset dari bidang konsep, keyakinan, atensi, sikap tidak merasa, Kelaziman, serta semacamnya. Observasi membolehkan pengamat buat memandang bumi begitu juga diamati oleh subyek riset, situasi kehidupan disaat itu, menjaring makna kejadian dari bidang penafsiran subyek, meringkus kehidupan adat dari bidang pemikiran serta panutan para subyek pada kondisi durasi itu. Dalam riset ini, periset memakai tehnik Partisipant observation tidak mencermati dengan cara langsung namun cuma selaku pengamat serta memperoleh pengalian datad ari pemantauan lansung pada jurnalis.

2. Wawancara

Wawancara merupakan obrolan dengan makna khusus. Obrolan itu dicoba oleh 2 pihak, pewawancara yang mengajukan permasalahan serta dijawab oleh subjek tanya jawab itu. Sedangkan menurut S. Margono, wawancara (interview) merupakan perlengkapan pengumpul data dengan metode mengajukan beberapa persoalan dengan cara perkataan buat dijawab dengan cara perkataan pula. Karakteristik penting interview merupakan kontak langsung antara pelacak data( interviewer) serta asal usul data( interview) (Margono, 2017)

3. Dokumentasi

Dokumentasi Yakni pengumpulan informasi yang didapat lewat dokumendokumen, paling utama arsip- arsip, buku- buku mengenai opini teori- teori, ajaran, hukum serta lain- lain yang berkaitan dengan riset. Tata cara ini periset maanfaatkan buat mendapatkan informasi tentang asal usul berdirinya, bentuk kepengurusan, jumlah karyawan, pendapatan, pengeluaran, alat serta infrastruktur dan perkembanganperkembangan yang digapai oleh MTs Nurul Huda. 
Hasil Penelitian

\section{Pembelajaran materi Ahlussunnah Wal Jama'ah Pada Siswa MTs Nurul Huda.}

Sebagai Madrasah yang ajaran Ahlusunnah wal Jama'ah an-Nahdliyah Madrasah MTs Nurul Huda mempunyai Visi yaitu Beriman, bertaqwa, berilmu pengetahuan, berteknologi dan berakhlakul karimah dengan berlandaskan Ahlussunnah wal Jama'ah. Madrasah ini memiliki beberapa kegiatan amaliah Ahlussunnah wal Jama'ah anNahdliyah yang selain sebagai bentuk ibadah dan pengamalan tradisi NU, rutinan amaliah yang dilakukan juga sebagai bentuk upaya membentengi siswa dari ancaman paham radikalisme. Kegiatan rutin yang terjadwal sebagai bentuk pembiasaan siswa yang merupakan salah satu cara untuk mengenal lebih dalam yang bertujuan untuk menumbuhkan rasa cinta terhadap amaliah tradisi Ahlussunnah wal Jamaah an-Nahdliyah. Dengan tumbuhnya rasa cinta maka muncul rasa memiliki yang secara perlahan dapat menguatkan keyakinan siswa untuk tetap menjaga eksistensi dan lestarinya amaliah Ahlussunnah wal Jamaah an-Nahdliyah.

Bapak Salim,S.Pd Selaku Kepala Madrasah menegaskan: "Amaliah yang kita laksanakan di madrasah itu bukan semata-mata untuk menggugurkan kewajiban sebagai lembaga tidak, kita lebih pada hal yang memang itu harus dilaksanakan sebagai generasi yang menyatakan diri sebagai pelajar yang berada di Ma'arif, mau tidak mau yang bersekolah disini harus ikut tatacara dan aturan main yang berada di Ma'arif termasuk disitu ada pembelajaran mapel Aswaja, mau tidak mau maka harus ikut itu. Atau yang lain misalkan kita menjalankan istighatsah rutin, ziaroh makam dan seterusnya kalau itu nanti aturan itu dikenakan kepada guru atau siswa maka harus diikuti dalam rangka menanamkan akidah NU sebagai ciri khas. Dan itu tidak semata hanya melaksanakan tahlilan dan istighatsah, tapi juga diberi wawasan bahwa istigosah itu seperti ini, ini menjadi salah satu amaliah NU dan sebagainya". (wawancara, 24, 08, 2021)

Hal yang serupa juga disampaikan oleh Bapak Aqshon Budairi, S.Th.I untuk penguatan doktrin Aswaja pada siswa khususnya dalam penguatan amaliah NU sebagai cara pelestarian melalui pembiasaan. "Untuk yang ada disini amaliahnya biasanya tahlilan, istighatsah, ziaroh kubur, terus Nahdlatul Tulab, berupa sholawatan dan majelis dzikir\|."(wawancara, 24, 08, 2021) Adapun amaliah-amaliah Ahlussunnah wal Jamaah an-Nahdliyah yang diterapkan di MTs Nurul Huda, yaitu Maulid Nabi, Istighatsah rutin, Ziarah makam rutin 3 bulan sekali, dan Khotmil Qur"an.

\section{Upaya guru Pendidikan Agama Islam dalam menanamkan nilai-nilai Ahlussunnah Wal Jama'ah Pada Siswa MTs Nurul Huda.}

Upaya MTs Nurul Huda dalam penguatan doktrin Aswaja NU pada siswa sebagai benteng paham radikalisme diantaranya sebagai berikut:

\section{Pembelajaran}

Berdasarkan observasi dan wawancara yang dilakukan salah satu upaya penguatan akidah maupun amaliah Aswaja dilakukan melalui kegiatan belajar mengajar (KBM). Mata pelajaran Aswaja Ke-NU-an merupakan salah satu muatan lokal yang merupakan ciri khas. Hal ini disampaikan oleh Kepala Madrasah MTs Nurul Huda sebagai berikut: "Secara umum penguatan akidah melalui mata pelajaran, yaitu mata pelajaran Aswaja dan Ke-NU-an, itu adalah menjadi satu pelajaran muatan lokal yang menjadi ciri khas ma'arif.". (wawancara, 24, 08, 2021) Pernyataan tersebut selaras dengan kurikulum Madrasah yang menjelaskan 
Jurnal Edumaspul, 5 (2), Year 2021- 470

(Yulistian Hartini, Devy Habibi Muhammad, Ari Susandi)

bahwa MTs Nurul Huda mempunyai tiga muatan lokal, yakni Aswaja/Ke-NU-an, Imla' dan Tahfidz. Adapun salah satu tujuan dari muatan lokal Aswaja/Ke-NUan adalah Menanamkan nilai-nilai dasar Aswaja kepada peserta didik sebagai pedoman dan acuan dalam menjalankan ajaran Islam.

\section{Pembahasan \\ Pembelajaran materi Ahlussunnah Wal Jama'ah Pada Siswa MTs Nurul Huda.}

MTs Nurul Huda melakukan upaya penguatan akidah maupun amaliah Aswaja melalui kegiatan belajar mengajar (KBM) dengan memanfaatkan mata pelajaran Aswaja sebagai salah satu muatan lokal yang merupakan ciri khas dari lembaga pendidikan ini. Adapun salah satu tujuan dari muatan lokal Aswaja adalah Menanamkan nilai-nilai dasar Aswaja kepada peserta didik sebagai pedoman dan acuan dalam menjalankan ajaran Islam. Melalui KBM inilah siswa diberikan gambaran, bahkan mengomparasikan pola pemikiran Nahdlatul Ulama dengan golongan lain sebagai bentuk penguatan doktrin pada siswa. Sehingga siswa tau bahwa amaliah NU merupakan amaliah yang mempunyai dasar dan bukan hanya sekedar bid'ah yang muncul tanpa alasan. (Budairi, 2021)

Dari keterangan tersebut strategi yang digunakan terlihat bagaimana madrasah sangat menghargai peserta didik sebagai insan akademis. Hal ini dibuktikan dengan upaya-upaya guru dalam mengembangkan wawasan siswa dalam menanamkan nilai-nilai ahlussunnah wal jama'ah. Dalam kegiatan pembelajaran ini siswa kelas 4 yang sudah mendapatkan modul pembelajaran ASWAJA ini akan mempelajarinya dan akan dipraktekan dengan amaliah yang dibantu oleh guru dan dielaborasikan dalam sistem pendidikan Madrasah.

\section{Upaya Guru Pendidikan Agama Islam Dalam Menanamkan Nilai-Nilai Ahlussunah Wal Jama'ah siswa di MTs Nurul Huda}

\section{Pembelajaran}

Upaya yang dilakukan dalam menanamkan nilai-nilai Ahlussunah Wal Jama'ah siswa di MTs Nurul Huda oleh guru Pendidikan Agama Islam adalah sebagai berikut:

\section{Pembiasaan}

Disamping penguatan sebagai ajaran serta lewat penataran, MTs Nurul Huda pula mengadakan penguatan amaliah dengan teknik penyesuaian ataupun penerapan dengan cara teratur (Zahroh, 2021). Dengan penyesuaian kegiatankegiatan amaliah dengan cara teratur serta terencana diharapkan berkembang rasa cinta serta mempunyai pada amaliah NU. Amaliah- amaliah yang dilaksanakan bukan semata- semata cuma buat mengugurkan peranan selaku majelis, hendak tapi suatu keharusan serta fakta rasa cinta keturunan yang menerangkan diri buat lalu menjunjung besar tradisi- tradisi versi Ahlussunah Wal Jamaah.

Semua kegiatan yang berkaitan dengan dasar dari amaliah Ahlussunah Wal Jamaah ini kemudian dibiasakan untuk menjadi ritus keagamaan, upaya ini dilakukan cukup efektif menurut apa yang disampaikan oleh Guru pendidikan agama Islam, "seperti tahlil dan sholat dhuha peserta sangat antusias, jadi untuk imam nya nanti bisa bergantian, dari kelas 7-9 untuk kelas 8 kebawah masih belum dapat bagian imam".

\section{Analisis Dampak Upaya Guru Pendidikan Agama Islam Dalam Menanamkan Nilai-Nilai Ahlussunah Wal Jama'ah siswa di MTs Nurul Huda}

Dampak dari kegiatan amaliyah Ahlussunnah Wal Jama'ah pada siswa 
MTs Nurul Huda adalah rasa tawadlu, baik pada orang tua ataupun guru di sekolah Perihal ini ditunjukkan anak didik pada saat anak didik mematuhi seluruh ucapan guru pada waktu penerapan kegiatan- kegiatan amaliyah itu. Bila seseorang partisipan ajar telah memiliki rasa tawadlu' hingga tujuan dari pembelajaran hendak terlaksana. (wawancara, 24, 08, 2021). menambahkan kedisiplinan anak didik, dalam melaksanakan kegiatan sholat dhuha di sekolah yang dicoba di saat sebelum jam pelatihan sampai akan membuat anak didik jadi tapat waktu. Terdapat pula buktinya yakni anak didik yang kerap berangkat pagi untuk sholat dhuha beijama' ah di sekolah dikala saat sebelum jam pengajian studi dimulai. Dengan adanya adaptasi kegiatan itu, sampai anak didik dengan sendirinya akan terjadinya kedisiplinan. (wawancara, 24, 08, 2021)

Dalam hal ini MTs Nurul Huda bisa melakukan aktivitas penerapan nilainilai Ahlussunah Wal Jama'ah, dengan harapan nantinya siswa MTs Nurul Huda sanggup menerapkannya dalam aturan kehidupan yang nyata di masyarakat. Dari penanaman nilai- nilai Ahlussunnah Wal Jama' ah yang terdapat di sekolah lewat aktivitas keimanan ini tujuannya merupakan agar partisipan ajar lebih menguasai serta sanggup melakukan aktivitas amaliyah- amaliyah itu kedalam kehidupan tiap hari di penduduk, tidak hanya itu guna menegakkan nilai- nilai Ahlussunnah Wal Jama' ah, yaitu tawasut, I'tidal, tasamuh, tawazun, amar ma'ruf nahi munkar. (wawancara, 24, 08, 2021)

\section{KESIMPULAN}

1. Menurut hasil riset, pengkajian Ahlussunnah Wal Jama' ah di MTs Nurul Huda ini dalam membagikan modul pembelajarannya telah serupa, ialah memakai RPP, strategi penataran, penilaian serta tata cara penataran ialah dengan memakai 2 tata cara penataran
1) tata cara khotbah, 2) tata cara dialog. Tidak hanya itu, terdapat angka kepribadian yang diutamakan oleh guru di MTs Nurul Huda, antara lain merupakan religius, jujur, keterbukaan, taat, tanggung jawab, menghormati keanekaan serta cinta tanah air.

2. Upaya-upaya yang dilakukan dalam penanaman nilai-nilai Ahlussunnah Wal Jama'ah pada siswa MTs Nurul Huda yaitu 1) Menggunakan materi Aswaja, menanamkan sikap 2) Tawasuth dan I'tidal (tidak membeda-bedakan/ adil kepada semua peserta didik/demokratis), Tasamuh (saling menghormati, menghargai, menerima perbedaan pendapat orang lain), Tawazun (tidak tergesa- gesa dalam mengambil keputusan/tindakan dalam hal apapun), Amr Ma'ruf nahi Munkar (berbuat "baik, tawadlu kepada guru maupun orang tua) 3) Membiasakan pelaksanaan kegiatan keagamaan atau amaliyah di sekolah yaitu: sholat dhuha berjamaah, wirid, sholawatan, al-banjari, istighosah, ziarah makam, yasinan, memperingati maulid Nabi Saw dan peringatan rojabiyah.

Dampak penanaman nilai- nilai Ahlussunnah Wal Jama' ah anNahdliyyah pada pelaksanaan nilai- nilai Ahlussunnah Wal Jamaah dalam kehidupan tiap hari anak didik MTs Nurul Huda yaitu( 1) berakhlakul karimah,( 2) mempunyai rasa keterbukaan pada teman,(3) mempunyai rasa tawadl' pada kedua orang yang lanjut usia dan pada guru di sekolah.( 4) melakukan penerapan nilai- nilai Aswaja yang telah dipraktikkan di sekolah.( 5) bersama menghargai, menghormati dalam bermacam perihal.

\section{Daftar Pustaka}

(Ali Rohmad. (2009). No Title. 345.

Adawiyah, R. (2019). MAKNA ISLAM SEBAGAI AGAMA RAHMATAN LIL 
ALAMIN PERSPEKTIF PARTAIPARTAI ISLAM PERIODE 2014-2019 (Studi terhadap Pernyataan Petinggi Partai Islam dalam Menanggapi Isu SARA). Imtiyaz: Jurnal Ilmu Keislaman, 3(2), 129-149. https://doi.org/10.46773/imtiyaz.v $3 \mathrm{i} 2.53$

Muhammad, D. H. (2020). Implementasi Pendidikan Humanisme Religiusitas Dalam. Edumaspul Jurnal Pendidikan, 4(2), 122-131.

Prasetiya, B., Hadi, S., \& Khoiriyah. (2018). Analisis Kuantitatif Korelasi Pendidikan Agama dalam Keluarga dan Motivasi Berprestasi Terhadap Hasil Belajar Pendidikan Agama Islam. Jurnal Al-Ta'dib, 11(2), 91108.

Sary, N. (2017). Mencegah Penyebaran Paham Radikalisme pada Sekolah. Manthiq, 2(2), 191-200.

Susandi, A. (2019). PENGAJARAN GURU PENDIDIKAN DASAR DI ERA MILLENIAL DALAM MEMBENTUK MORAL SISWA. Conciencia, 19(2), 85-98.

https://doi.org/10.19109/concienci a.v19i2.4405 